\title{
Phytopathology"
}

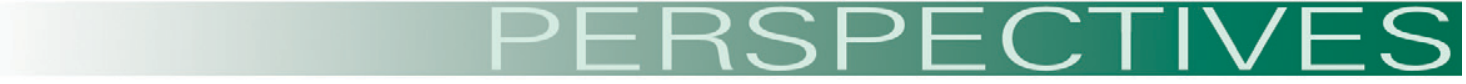

\section{The Epidemiology of Xylella fastidiosa; A Perspective on Current Knowledge and Framework to Investigate Plant Host-Vector-Pathogen Interactions}

\author{
Michael Jeger ${ }^{\dagger}$ and Claude Bragard
}

First author: Centre for Environmental Policy, Imperial College London, Silwood Park Campus, Ascot SL7 9LU, United Kingdom; and second author: Earth and Life Institute, UCLouvain, B-1348 Louvain-la-Neuve, Belgium.

Accepted for publication 22 October 2018.

\begin{abstract}
Insect-transmitted plant diseases caused by viruses, phytoplasmas, and bacteria share many features in common regardless of the causal agent. This perspective aims to show how a model framework, developed originally for plant virus diseases, can be modified for the case of diseases incited by Xylella fastidiosa. In particular, the model framework enables the specification of a simple but quite general invasion criterion defined in terms of key plant, pathogen, and vector parameters and, importantly, their interactions, which determine whether or not an incursion or isolated outbreak of a pathogen will lead to establishment, persistence, and subsequent epidemic development. Hence, this approach is applicable to the wide range of $X$. fastidiosa-incited diseases that have recently emerged in southern Europe, each with differing host plant, pathogen subspecies, and vector identities. Of particular importance are parameters relating to vector abundance and activity, transmission characteristics, and behavior in relation to preferences for host infection status. Some gaps in knowledge with regard to the developing situation in Europe are noted.
\end{abstract}

In recent years, there has been a marked increase in interest and attention given to newly emerging vectored diseases of plants, animals, and humans (Jones et al. 2008), including those caused by viruses. This is also of interest for important insect-transmitted bacterial diseases of plants. For example, in a general review of insect-transmitted bacterial diseases of plants, including Xylella fastidiosa, Spiroplasma spp., Liberibacter spp., and phytoplasmas, Perilla-Henao and Casteel (2016) pointed out that less work has been done compared with vectored virus diseases of plants. Similarly, in a general review of phloem-limited pathogens, Bendix and Lewis (2018) pointed out the commonalities between bacteria and viruses in their virulence strategies and posited that such commonality may form the basis for disease management strategies that are widely applicable. Interactions among plants, vectors, and bacteria are often poorly understood (Tamborindeguy et al. 2017) and constrain the ability to control the newly emerging diseases that result. The review by Tamborindeguy et al. (2017) focuses on the influence of bacteria on multitrophic interactions among plants, psyllids, and pathogens and stress that, as more organisms are studied, subtleties of the molecular interactions as well as of the effect of the bacteria on the psyllid host are being uncovered.

${ }^{\dagger}$ Corresponding author: Michael Jeger; E-mail: m.jeger@imperial.ac.uk

(C) 2019 The American Phytopathological Society
Furthermore, the review underlines gaps and lags in knowledge that may arise because the disease is newly emerging.

As with plant viruses, transmission of plant-pathogenic bacteria by insects goes beyond a purely physical association between vector and bacterium and involves aspects of host modulation that promote vector acquisition and plant-to-plant transmission (Orlovskis et al. 2015). A comparison of vector transmission of plant viruses and bacteria is made in Table 1. More generally, microbes, including bacterial pathogens and viruses, affect plant-insect interactions in many ways (Simon et al. 2017) that affect both plant and pathogen fitness, as described later in this perspective.

\section{THE CASE OF XYLELLA FASTIDIOSA}

$X$. fastidiosa causes a "classic" plant disease, Pierce's disease of grapevine, in the sense that it has been known for more than a century, even though its etiology was elucidated much later. A personal account was given by Purcell (2013) of the progress made in the 20th century and the paradigm shifts in research that have occurred during this time, notably from the discovery of a bacterial causal agent, whereas the disease was previously assumed to be caused by a virus. Today, the disease continues to pose severe problems in the production of many food crops, notably perennial tree fruit, and has recently reemerged as global plant health threat through its incursion into Europe (Sicard et al. 2018). For every advance that has been made in understanding and managing the 
diseases caused, the pathogen has proved to be adaptable and continues to provide surprises as well as new insights in research. The literature on $X$. fastidiosa is extensive, with some 460 references retrieved between 2015 and June 2018 (EFSA 2018a). Historically, the diseases caused have been characterized by episodic invasions into new regions and hosts in the Americas and, most recently, into Europe. Saponari et al. (2017) provide the first experimental confirmation that $X$. fastidiosa is the causal agent of olive quick decline syndrome in Apulia, Italy, and the current situation in Europe was summarized by the European Food Safety Authority (EFSA 2018a). The future potential distribution of $X$. fastidiosa in Italy has been predicted using a MaxEnt distribution model (Bosso et al. 2016) and for the EU territory in relation to climate change by Godefroid et al. (2018). This perspective takes into account the most recent invasions into Europe but also future invasions, and proposes to set a framework for understanding the plant host-vector- $X$. fastidiosa interactions that lead to invasion.

The current state of the epidemiology of Xylella fastidiosa is comprehensive, with extensive literature citations given in the recent review by Sicard et al. (2018). The key feature of the diseases caused by $X$. fastidios $a$ is that its development in a host population is entirely dependent on plant-to-plant transmission by insect vectors, and encapsulates "the inseparable ecological trinity" of plant, vector, and pathogen developed by Walter Carter in the 1930s in the context of plant viruses (Carter 1939; Gutiérrez et al. 2013). The complication is that, for each component (host plant, bacterium, and vector), there is considerable diversity (EFSA 2018a). The bacterium has many subspecies and other infraspecific forms (EFSA 2018a; Sicard et al. 2018); the vectors are many and, in principle, include any xylem-feeding insect (Almeida et al. 2005).
The host range is one of the widest for any plant pathogen but is eclipsed by the aphid-transmitted Cucumber mosaic virus, with more than 1,000 host plant species (Roossinck 2002) and includes both economic crops and plants in natural or unmanaged communities (EFSA 2018a,b). Even within subspecies, there can be host specialization (Nunney et al. 2013; Sanderlin 2017). There was a strong effect of strain variation arising from different hosts (Lopes et al. 2010). Multiplication rate of different strains affected symptom severity and bacterial persistence in alfalfa, with some strains dying out. Similarly, vector competence is associated with host species and strain variation (Lopes et al. 2009). Transmission efficiency can vary according to vector species, host species and cultivars, and $X$. fastidiosa strain (Almeida 2016). Given this diversity of strain variants, it is largely unknown whether coinfection of hosts leads to the types of interactions reported for some plant viruses which affect both transmission and establishment parameters (Blaisdell et al. 2015).

The vectors of $X$. fastidiosa are xylem-feeding insects and their biology in relation to disease epidemiology was reviewed by Redak et al. (2004). A particular aspect reviewed was the establishment and invasion by a new exotic sharpshooter vector in California Almeida and Purcell (2003). Although most diseases in the Americas occur on nonnative crop plants, the bacterium is considered to be endemic; hence, the increased threat to production was the consequence of an invasive and efficient exotic vector acquiring an endemic pathogen. The introduction of the invasive glassy-winged sharpshooter to California in the late 1980s (Stenger et al. 2010) eventually led to epidemics of oleander leaf scorch (Purcell et al. 1999) and Pierce's disease (Hopkins and Purcell 2002; Perring et al. 2001) in Southern California. By contrast, in Europe,

TABLE 1

Comparison of the mode of transmission for insect-transmitted bacteria and viruses ${ }^{\mathrm{a}}$

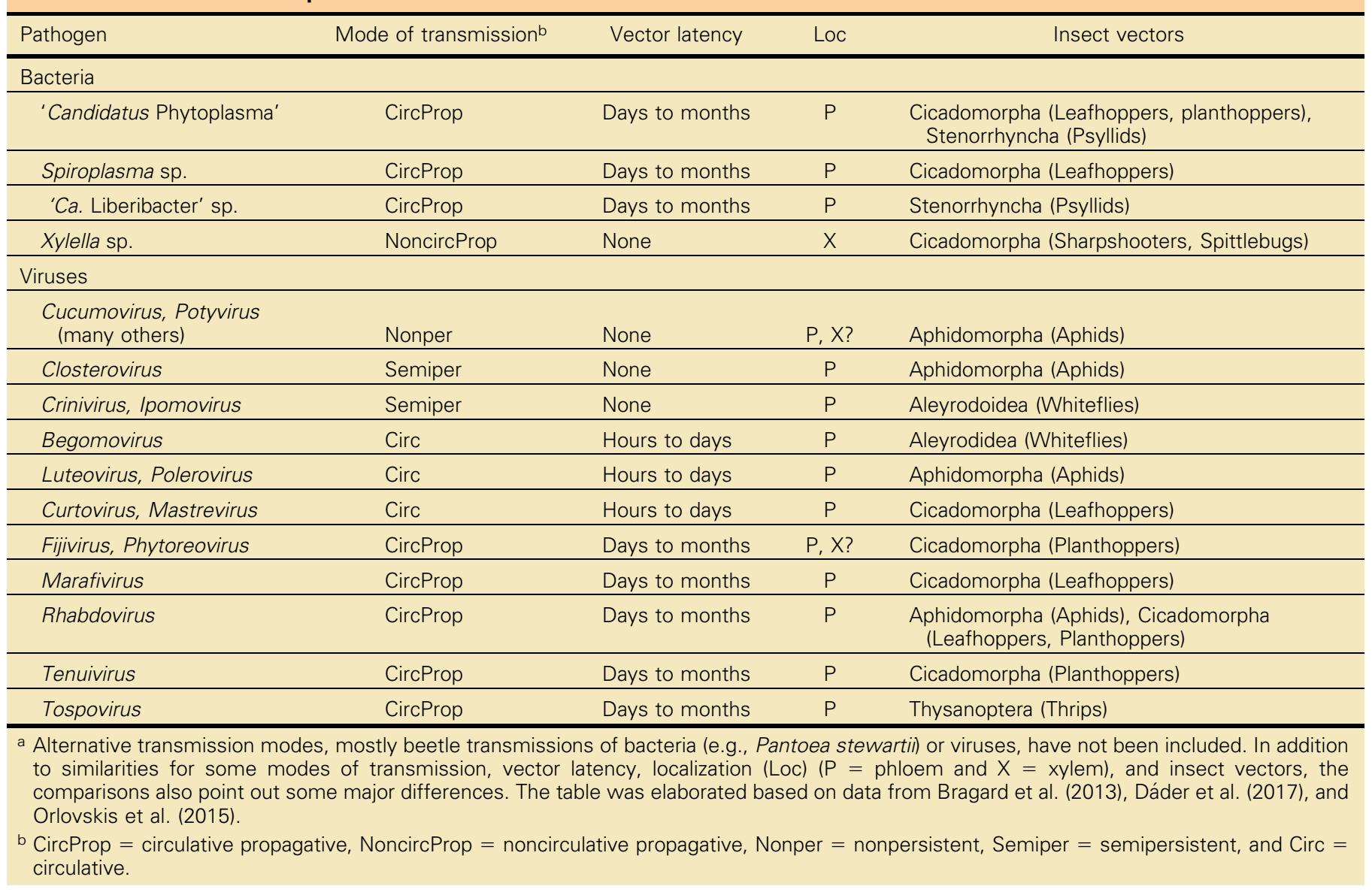


only a few sharpshooter species but high numbers of spittlebug species are present. Endemic spittlebugs, in particular the meadow spittlebug Philaenus spumarius, are vectors on olive in Italy (Cornara et al. 2017a,b). Although the role of $P$. spumarius as vector in Europe has been confirmed, other potential insect vectors such as Neophilaenus campestris, in association with different $X$. fastidiosa subspecies, remain a possibility. Surveys conducted in three regions of Spain showed the presence of spittlebugs, including $N$. campestris, as potential vectors but not the sharpshooter vectors found in the Americas (Lopes et al. 2014). X. fastidiosa has subsequently been reported in the Balearics and Alicante (EFSA 2018a). Thus, for Europe, up to now, the threat arises from an endemic vector acquiring and spreading an exotic and introduced pathogen.

The range of potential vectors is worrying in relation to future outbreaks and invasions. It is assumed that all xylem-feeding insects can be vectors (Almeida et al. 2005). Some 43 Auchenorrhyncha species were identified in studies on citrus variegated chlorosis in Argentina (Dellapé et al. 2016), some of which were dominant in citrus, others in surrounding vegetation, with each of the dominant species testing positive for $X$. fastidiosa using molecular detection methods. Bacterial populations in the meadow spittlebug were one to two orders of magnitude smaller than those typically found in Cicadellidae vectors but there was a direct relationship between numbers and transmission to plants (Cornara et al. 2016). Seasonal abundance of insect vectors has been reported in the United States and Europe (Ben Moussa et al. 2016; Overall and Rebek 2015). Puerto Rico is currently free of $X$. fastidiosa but populations of potential Cicadellidae vectors were monitored in coffee and citrus, both susceptible hosts (Brodbeck et al. 2017). One potential vector species was found in coffee and an associated shade host but none on citrus. Despite these complexities, there is a need to consider each component-bacterium, vector, and host plant-and their interactions in epidemiological analysis to inform disease control strategies such as those reviewed by Overall and Rebek (2017).

In terms of introduction into Europe, although $X$. fastidiosa was detected for the first time in 2013, in-depth analysis of datasets based on positive polymerase chain reaction (PCR) samples from the French Department Corse-du-Sud, by inferring pathogen dynamics form temporal count data, by Soubeyrand et al. (2018) suggest that the introduction might have occurred as early as in the 1980s. In terms of environmental factors, those related to soil, nutrition, and soil-water relationships and their interactions played a significant role in the expression of Pierce's disease in grapevine, possibly through effects on constitutive or induced resistance which might be exploited in disease management (Costello et al. 2017). Climax modeling was used to show that $X$. fastidiosa and vectors could survive in much of the coastal regions of Australia, that much of the native flora was also vulnerable, and, thus, that preparedness for such an incursion would be necessary (Rathé et al. 2012). Similarly, the impacts of $X$. fastidiosa on yield, tree performance, and longevity (Sisterson et al. 2012) are noted but not considered further.

Although we appreciate the paradigm shift from supposed virus to demonstrated bacterium as commented on by Purcell (2013), in our view, the framework described in this perspective is applicable to all vectored plant diseases and, as such, could be developed further as a new paradigm shift. We fully appreciate that, as a consequence, this perspective does not cover all the ways in which the epidemiology of $X$. fastidiosa can be investigated; notably, the pathways that may lead to the introduction and spread of the pathogen into a new region, country, or continent; and the influence of environmental factors on establishment, factors which have become important in the last decade in Europe (EFSA 2018a). Thus, the main question raised in this perspective is the extent to which research on the epidemiology of vectored plant virus diseases is applicable to vectored bacterial diseases, in particular those caused by $X$. fastidiosa. In so doing, we will use a modeling framework developed for plant-virus-vector interactions, noting both the similarities and differences.

The purpose of this perspective is not to model diseases caused by the genus Xylella and its many complexities but to present a "point of view" (= perspective) on a simplified modeling framework which could be adapted and made specific to a particular set of circumstances. The perspective is also not aimed specifically at mathematical modelers but at plant disease epidemiologists more generally, to make them more aware of an approach that has been found useful in plant virus epidemiology and, more generally, with vector-borne diseases of animals and humans. We would argue that convincing plant disease epidemiologists of the value of looking at insect-transmitted plant diseases is both useful and novel, because most plant disease epidemiologists do not deal with such diseases. The main points and message made are as follows.

i. A common approach to modeling insect-transmitted plant diseases can be formulated regardless of the pathogen taxa.

ii. This framework emphasizes the key role of transmission in determining disease dynamics, especially during the early stages of invasion, while recognizing that other approaches, especially concerning disease spread, are essential.

iii. The complexities of Xylella epidemiology can be incorporated into the framework depending on the modeling objectives.

\section{A FRAMEWORK FOR MODELING X. FASTIDIOSA EPIDEMIOLOGY}

For $X$. fastidiosa epidemiology, models have been proposed, mostly concerned with spread but with the vector considered only implicitly. Spatial analysis in almond orchards showed a mainly aggregated pattern of disease, with some influence on the pattern by susceptible cultivars (Groves et al. 2005). Park et al. (2011) investigated the relationship between Pierce's disease incidence and occurrence with the surrounding environment, providing useful spatial information on the disease in vineyards. Spatial and spatiotemporal models are valid in their own right, and certainly in terms of disease expansion following initial invasion and establishment. These models are essential in determining the strategies that can be taken to constrain further spread, and some articles do focus on such approaches. An explicit spatially dependent simulation model was developed and used to analyze the spread of disease affecting olive in Apulia, Italy, and the potential efficacy of control measures (White et al. 2017). The model outputs showed the importance of long-distance jumps in vector movement, the importance of extending buffer zones, and the significant role of nonolive vegetation in increasing the rate of spread. An epidemiological approach to gearing disease surveillance to control interventions is given by Parnell et al. (2017). Riskbased control based on epidemiological information and a spatial mathematical model suggests that the use of a variable radius outperforms a strategy of constant-radius removal of infected plants (Hyatt-Twynam et al. 2017; Vicent and Blasco 2017). One approach, implicitly spatial, that can be taken is the use of network models to assess the risks of the movement of pathogens in plant trade (Jeger et al. 2007), certainly applicable to Xylella spp., but this is a very broad area that goes beyond the scope of this perspective. However, network analysis suggests that attempts to eradicate the disease from southern Italy are futile and this region will provide a pathogen reservoir for further spread (Strona et al. 2017), a suggestion which appears contrary to the current EU emergency legislation (EFSA 2018a).

Most attempts to model or analyze spatial spread of $X$. fastidiosa stress insect dispersal capacities and extrapolating empirical data on disease gradients rather than modeling the essential features of the 
initial rate of disease increase (Madden et al. 2000), an important parameter which indicates the speed at which the early epidemic develops, although additional model assumptions can affect the consistency of estimates (Roberts and Heesterbeek 2007).

In the model framework proposed, the vector (and host) population density is assumed to be constant. This assumption can hold approximately if the rates of increase and decrease are slow relative to the rates of acquisition and inoculation in the transmission process. The invasion criterion, written in words above, is derived directly from the underlying ordinary differential equations at the disease-free state, where the respective populations are constant. We note that this does not give the true $R_{0}$, which would be calculated by the Next Generation Matrix method (van den Bosch and Jeger 2017). It is also the case that derivation of $R_{0}$ is problematic when there is seasonality in any of the transmission parameters or host or vector population densities. However, there is theoretical work which shows how periodicities in the host (Wesley and Allen 2009) and vector (Bacaër 2007) populations can be taken into account to derive, in effect, an average $R_{0}$. For $X$. fastidiosa, a number of studies have indicated the role of seasonality in determining disease development. Seasonal variability in the vector population could lead to an eightfold reduction in within- and between-season disease spread (Gruber and Daugherty 2013). Plants inoculated late in the growing season are more likely to cure during the winter than plants inoculated early in the season (Cao et al. 2011; Feil et al. 2003; Lieth et al. 2011). Accordingly, there appears to be important seasonal effects on pathogen dynamics. This would, in principle, affect the way in which the transitions between states in the SEIR model are specified; for example, perhaps as a return transition from the infectious to the exposed (or possibly susceptible) class.

Despite these qualifications, the main utility of the proposed approach is that it enables the plant, virus, and vector components of an epidemic, and their interactions, to be integrated into a single model framework and their relative contribution to epidemic

TABLE 3

Derived terms and their interpretation in the invasion criterion obtained for a simple susceptible-exposed-infectious-removed (SEIR) model of a vectored plant virus disease as described heuristically in the text

\begin{tabular}{|c|c|}
\hline Term in invasion criterion & In symbolsa \\
\hline $\begin{array}{l}\text { Probability a viruliferous vector becomes } \\
\text { inoculative } \eta /(\eta+\alpha)\end{array}$ & $\eta /(\eta+\alpha)$ \\
\hline $\begin{array}{l}\text { Feeding time per inoculative vector per unit } \\
\text { time } \times \text { inoculation rate }\end{array}$ & $\lambda_{1} \Phi \top$ \\
\hline $\begin{array}{l}\text { Average time an inoculative vector stays } \\
\text { inoculative }\end{array}$ & $1 /(\tau+\alpha)$ \\
\hline $\begin{array}{l}\text { Probability that an infected plant becomes } \\
\text { infectious }\end{array}$ & $\gamma /(\gamma+\beta)$ \\
\hline $\begin{array}{l}\text { Feeding time per nonviruliferous vector per un } \\
\text { time } \times \text { acquisition rate }\end{array}$ & $\lambda_{2} \Phi \top$ \\
\hline $\begin{array}{l}\text { Average time an infectious plant remains } \\
\text { infectious }\end{array}$ & $1 /(\zeta+\beta)$ \\
\hline Vectors per plant & $\mathrm{P} / \mathrm{K}$ \\
\hline \multicolumn{2}{|c|}{$\begin{array}{l}\text { a Symbols: } \eta=\text { rate at which a viruliferous vector becomes } \\
\text { inoculative, } \alpha=\text { death rate (birth rate), } \lambda_{1}=\text { inoculation rate, } T= \\
\text { time spent feeding per visit, } \gamma=\text { rate at which an infected plant } \\
\text { becomes infectious, } \beta=\text { mortality rate (turnover rate), } \lambda_{2}=\text { acquisition } \\
\text { rate, } \tau=\text { rate at which an inoculative vector loses the ability to } \\
\text { inoculate, } \zeta=\text { rate at which an infectious plant loses infectiousness, } \\
P=\text { vector population size (constant), and } \mathrm{K}=\text { host population } \\
\text { size }(\text { constant). The invasion criterion is the product of these terms: } \\
\eta /(\eta+\alpha) \times \lambda_{1} \Phi \top \times 1 /(\tau+\alpha) \times \gamma /(\gamma+\beta) \times \lambda_{2} \Phi T \times P / K \times 1 /(\zeta+\beta) \text {. If the } \\
\text { criterion has a value }>1 \text {, then the disease will invade. }\end{array}$} \\
\hline
\end{tabular}

development assessed. Numerical analysis of the model above showed that vector abundance, activity, and behavior, in relation to transmission, are important determinants of disease dynamics (Jeger et al. 2004), and we take up these elements below in relation to X. fastidiosa. We also note that there are examples of recent modeling studies in which this type of framework has been used to answer strategic questions concerning epidemiology and deployment of host resistance and other disease control strategies and, in doing so, have addressed issues relevant for $X$. fastidiosa management (Kyrkou et al. 2018; Sisterson and Stenger 2018).

Application and relevance for $\boldsymbol{X}$. fastidiosa. The framework developed here allows an invasion criterion to be specified for which some if not all of the parameters are known for some vector-host $-X$. fastidiosa combinations. The question then arises as to whether this approach is applicable to $X$. fastidiosa, given the complexities noted above related to plant-bacterium-vector interaction. As already stated, we do not propose a specific model for diseases caused by $X$. fastidiosa but, rather, a modeling approach which includes the key epidemiological parameters influencing the initial invasion of disease and which, because of its simplicity, can be adapted for different purposes. The composite parameters that determine whether or not a disease can invade and establish (Table 3 ) in a new location are common to all diseases caused by $X$. fastidiosa. We argue that their epidemiology represents variations on a common theme. The problem is more in how new manifestations of disease can occur in the future and whether or not these are predictable.

First, we substitute "bacteriferous" for viruliferous. Second, we note that the bacterium is restricted to the xylem, and transmission can only occur with xylem-feeding insects, unlike the case with most viruses (and other insect-borne bacteria), where transmission is from the phloem (Table 1). In our view, this fact does not fundamentally affect the applicability of the framework developed for viruses. Many viruses can occur and move systemically in the xylem as well as the phloem but often it is not clear whether transmission by insects occurs from or to the xylem. Dáder et al. (2017) report transmission occasionally to the xylem for species of Alfomovirus, Caulimovirus, Cucumovirus, Crinivirus, Potyvirus, and Waikavirus, all noncirculative viruses. Phytoreovirus-like sequences have been isolated from the salivary glands of the xylem-feeding Homalodisca vitripennis (Katsar et al. 2007). Turnip mosaic virus can move systemically through the phloem and the xylem (Wan et al. 2015). For some leafhoppers such as Circulifer tenellus, ingestion of both phloem and xylem is necessary to obtain high rates of ingestion (Stafford and Walker 2009; Stafford et al. 2012). As noted by Novotny and Wilson (1997), the evolutionary transitions from phloem to xylem feeding in species of the order Hemiptera may place an energetic constraint on the minimum insect body size.

At this point in time, the modeling approach described has not been followed for Xylella spp.-incited diseases. In this perspective, we now look at the various components involved in the dynamics of a vectored plant disease, as summarized in Table 3, and consider their relevance to Xylella spp. epidemiology. Due to the many hosts and infraspecific variation in $X$. fastidiosa, the lengths of the plant latent periods have been estimated for only a few crops. The time to symptom development following insect inoculation is highly variable for several crops (Hill and Purcell 1995; Lopes et al. 2005; Saponari et al. 2016), ranging from days to more than 1 year; however, less is known in the field under natural infection. Recently, it has been shown that previsual-symptom detection of infection is possible in olive through airborne imaging of plant functional traits (Zarco-Tejada et al. 2018). However, the key epidemiological parameter is not the time to symptoms but the plant latent period (i.e., the time from infection to acquisition by the vector, whether from systemic or localized infection) (Hill and Purcell 1995). This parameter was investigated by Hill and Purcell (1997) but very 
much depends on the host plant-vector system investigated. A diseased tree, once infectious, is likely to remain infectious so long as the xylem remains functional and vectors continue to feed. Acquisition rate may vary according to disease progress on an individual tree. The model basically assumes that transitions from the infectious to the removed class have exponential distributions, thus giving an estimate of the mean infectious period. There are ways of incorporating different assumptions on these transitions but, again, these are beyond the scope of this perspective.

There is more information on at least some vectors, as described below, but vector activity within a crop population is largely unexplored. It is also the case that, following acquisition, the bacterium is restricted to the foregut (Almeida et al. 2005) and, hence, the vector latent period (before inoculation) would be very short or nonexistent (Almeida et al. 2005) and yet the bacterium multiplies there, presumably for the life of the vector. Therefore, $X$. fastidiosa corresponds to a noncirculative propagative bacterium, a case not described for persistent plant viruses, where movement from the foregut to the hemocyl and to the salivary glands would be the norm, leading to an extended vector latent period. We note also that the terminology used for plant virus vector transmission can have a different interpretation for those working with $X$. fastidiosa vectors. Bragard et al. (2013) made an attempt to systematically review all of the virus vectors, with three timedependent figures: one for acquisition, another one for retention, and a final one for inoculation. Killiny and Almeida (2013) proposed similar steps for their detailed study of the interaction of $X$. fastidiosa with its vectors. Studies have mostly focused on acquisition access period and inoculation access period but it has proved difficult to provide a very clear picture from experimental studies, probably because of high variation depending on the host plant, conditions, level of bacteria in the plants, and so on. This being said, if we follow Almeida et al. (2005), acquisition is almost immediate after feeding, there is no latency between acquisition and ability to inoculate (although vector residence times and behavior would affect this), retention is over the whole life of the adult or nymphs (but without transstadial passaging), and inoculation would continue with the life of the insect stage considered.

\section{VECTOR POPULATION ABUNDANCE AND ACTIVITY}

The population abundance of vectors (scaled by the number of host plants) is one component of the invasion criterion. Although aspects of the dynamics of insect-transmitted pathogens such as $X$. fastidiosa are related to vector abundance, many aspects of vector reproductive biology are poorly understood. Key nutritional factors involved in glassy-winged sharpshooter egg production and, hence, population growth are described by Sisterson et al. (2017). Although Sisterson et al. (2017) demonstrated that adult diet affects glassy-winged sharpshooter egg production and, hence, rates of population growth, key nutritional factors affecting egg maturation remain to be determined. Thus, there is a greater need to study vector reproduction biology and mortality to better understand population growth and disease spread (Sisterson and Stenger 2016; Sisterson et al. 2018).

A key question is the effectiveness of vector control in $X$. fastidiosa epidemiology. The dynamics of the glassy-winged sharpshooter were monitored in citrus, grapevine, and stone fruit in the San Joaquin valley in California before and after a control program was introduced (Park et al. 2006). The low numbers of vectors following spray treatment make it unlikely that statistically significant relationships with disease could be found in the different crops at the spatial scale considered. Monitoring of vectors in different agricultural crops and alfalfa fields subject to different management, including insecticide treatments, was made over 14 months in California (Wistrom et al. 2010). Recommendations on vector control to reduce vector populations and inoculum presence were made. However, vector control using insecticides reduced vector populations but had little effect on disease prevalence (Daugherty et al. 2015). The spread of disease may be reduced but the effect seems highly dependent on past history in the vineyard and may take a number of seasons to become apparent. The relatively small effect on disease prevalence was attributable, in part, to low regional vector population levels arising from area-wide control programs.

Winged adults, because of their high mobility and persistent association with the bacterium, are mostly responsible for $X$. fastidiosa spread. Vector activity within and between crops is another component of the invasion criterion. Spread can be predominantly from alternative crops to grapevine or from grapevine to grapevine in California, depending on the season (Hopkins and Purcell 2002), or exclusively from citrus to citrus in Brazil, regardless of the presence of orchard weeds known to harbor the bacterium. Vector movement to grapevine from adjacent citrus plantings under different irrigation treatments in California was monitored and net dispersal rates calculated (Krugner et al. 2012). There appeared to be an element of random rather than oriented movement, perhaps indicating an inability of the vector to respond to long-distance visual or olfactory cues (Patt and Sétamou 2007). With the introduction of the invasive glassy-winged sharpshooter, the vector overwintered on citrus, reaching large populations of 1 to 2 million sharpshooters/ha moving subsequently to adjacent grapevine (Coviella et al. 2006). Together with Blua and Morgan (2003), these two articles provide almost the only published information available for within-crop activity of vectors and movement from plant to plant.

There is much less information available on the population abundance of Philaenus spumarious in Europe. It is anticipated that much information will become available on the population abundance of this confirmed vector of $X$. fastidiosa in Mediterranean olive groves as part of an EFSA procurement project ("Collection of data and information on biology and control of vectors of $X$. fastidiosa"). This study is collecting data on nymph densities at different sites. At the site with highest population densities, there were averages of 21 and 30 nymphs $/ \mathrm{m}^{2}$ in 2016 and 2017, respectively (EFSA 2018a).

\section{VECTOR TRANSMISSION}

Acquisition rate and inoculation rate are important determinants of vector-borne disease dynamics. Transmission in terms of acquisition and inoculation of $X$. fastidiosa by vectors has been the subject of many studies, both qualitative and quantitative. Chatterjee et al. (2008) contrasted the biology of the bacterium in the plant and in the vector, contrasting the traits that determine movement within the plant with those governing acquisition and inoculation by the sharpshooter vectors. Daugherty and Almeida (2009) estimated these parameters for two vectors, one native and one invasive, of $X$. fastidios $a$ in grapevine, and also showed the dependence of transmission on temperature. These estimates effectively decoupled vector numbers from acquisition and showed large differences in the transmission efficiency of the two vectors. It seems logical to suppose that acquisition efficiency would be related to the bacterial populations in the plant and that low bacterial populations would serve as an inefficient reservoir for acquisition (Almeida et al. 2005). However, Rashed et al. (2011) found no significant relationship between grapevine cultivar susceptibility to $X$. fastidiosa expressed as bacterial populations in petioles and transmission efficiency from these plants, although innate vector preferences for different cultivars may have confounded the relationship. Because the bacterium is restricted to the foregut (Purcell and Finlay 1979), the number of bacterial cells per insect is low. However, very few live bacterial cells in the vector's foregut are required for transmission (Hill and Purcell 1995). At the moment, 
1979) but not citrus (Krugner et al. 2000; Marucci et al. 2003). When confined to infected plants, there was a reduction in feeding on symptomatic but not on asymptomatic plants (Marucci et al. 2005). These results suggest that early asymptomatic infections may be an effective source of $X$. fastidiosa for subsequent disease spread. At the present time, there seems to be no direct evidence that vector preference for diseased or healthy hosts is conditional upon whether the vector has acquired the bacterium.

\section{CONCLUSIONS}

This perspective aims to show that insect-transmitted diseases have many features in common regardless of whether the causal pathogen is a bacterium, phytoplasma, or virus. A model framework can be developed that encapsulates the essential interactions between the pathogen, plant, and insect vector in terms of key epidemiological parameters, from which a criterion can be developed that determines whether the pathogen would establish, persist, and lead to an epidemic in a host population. As has been pointed out by many workers, $X$. fastidiosa induces complex diseases with much infraspecific variation in the bacterium; an extensive host range, including both economic crops and natural vegetation; and a multitude of potential xylem-feeding insect vectors. Given this complexity, it is understandable why individual components specific to a particular system have been researched. However, especially in cases where new outbreaks occur such as the recent invasions into Italy, France, and Spain, it is important that the multilevel interactions between the range of $X$. fastidiosa subspecies, hosts species, and (currently) restricted number of known vectors are investigated in a holistic way. The model framework developed in this perspective, although in many ways simplistic, is one approach that can be taken. Where the parameter values can be estimated for a specific system, then their relative importance in determining whether an incursion or isolated outbreak will lead to a full-blown epidemic in time and space can be assessed.

For $X$. fastidiosa, there are some basic gaps in knowledge and elements that need to be incorporated in the simple framework presented.

1. For a given host what is the relationship between bacterial development and time to symptoms, and the ability of a (given) vector to acquire the bacterium?

2. What is the basis for vector preference for healthy or asymptomatic plants, and is this affected in any way by whether the vector carries the bacterium?

3. Does bacterial multiplication in the foregut affect in any way vector life history, behavior, and activity, or modulate inoculation efficiency? (It is well known that insect endosymbionts play a major role in providing the insect with amino acids lacking in the insect diet; especially for xylem-feeding insects, the challenge is a major one as compared with phloem-feeding insects.)

4. How important is seasonality for vector abundance and activity and what is the best way to incorporate this?

5. Could coinfection with bacterial variants in the plant or in the vector affect transmission in ways reported for plant viruses?

6. Can the phenomenon of overwintering curing effect be generalized to hosts other than grapevine and incorporated into the framework through seasonal effects on transmission and vector parameters?

\section{LITERATURE CITED}

Almeida, R. P. P. 2016. Xylella fastidiosa vector transmission biology. Pages 841-850 in: Manual of Security: Sensitive Microbes and Toxins. D. Liu, ed. CRC Press, Boca Raton, FL.

Almeida, R. P. P., Blua, M. J., Lopes, J. R., and Purcell, A. H. 2005. Vector transmission of Xylella fastidiosa: Applying fundamental knowledge to generate disease management strategies. Ann. Entomol. Soc. Am. 98: $775-786$.
Almeida, R. P. P., and Purcell, A. H. 2003. Homalodisca coagulate (Hemiptera, Cicadellidae) transmission of Xylella fastidiosa to almond. Plant Dis. $87: 1255-1259$.

Bacaër, N. 2007. Approximation of the basic reproductive number R0 for vector-borne diseases with a periodic vector population. Bull. Math. Biol. 69:1067-1091.

Bendix, C., and Lewis, J. D. 2018. The enemy within: Phloem-limited pathogens. Mol. Plant Pathol. 19:238-254.

Ben Moussa, I. E., Mazzoni, V., Valentini, F., Yaseen, T., Lorusso, D., Speranza, S., Digiaro, M., Varvaro, L., Krugner, R., and D'Onghia, A. M. 2016. Seasonal fluctuations of sap-feeding insect species infected by Xylella fastidiosa in Apulian olive groves of southern Italy. J. Econ. Entomol. 109:1512-1518.

Blaisdell, G. K., Zhang, S., Bratburd, J. R., Daane, K. M., Cooper, M. L., and Almeida, R. P. P. 2015. Interactions within susceptible hosts drive establishment of genetically distinct variants of an insect-borne pathogen. J. Econ. Entomol. 108:1531-1539.

Blua, M. J., and Morgan, D. J. W. 2003. Dispersion of Homalodisca coagulata (Hemiptera: Cicadellidae), a vector of Xylella fastidiosa, into vineyards in Southern California. J. Econ. Entomol. 96:1369-1374.

Bosso, L., Di Febbraro, M., Cristinzio, G., Zoina, A., and Russo, D., 2016. Shedding light on the effects of climate change on the potential distribution of Xylella fastidiosa in the Mediterranean basin. Biol. Inv. 18:1759-1768.

Bragard, C., Caciagli, P., Lemaire, O., Lopez-Moya, J. J., MacFarlane, S., Peters, D., Susi, P., and Torrance, L. 2013. Status and prospects of plant virus control through interference with vector transmission. Annu. Rev. Phytopathol. 51:177-201.

Brodbeck, B. V., Andersen, P. C., Oden, S., Mizell, R. F., McKamey, S. H., and Zapata, M. 2017. The distribution of Cicadellinae leafhoppers and other Auchenorrhyncha on coffee and citrus in Puerto Rico. Environ. Entomol. 46:511-520.

Cao, T., Connell, J. H., Wilhelm, M., and Kirkpatrick, B. C. 2011. Influence of inoculation date on the colonization of Xylella fastidiosa and the persistence of almond leaf scorch disease among almond cultivars. Plant Dis. 95: 158-165.

Carter, W. 1939. Populations of Thrips tabaci, with special reference to virus transmission. J. Anim. Ecol. 8:261-276.

Chamchod, F., and Britton, N. F. 2011. Analysis of a vector-bias model on malaria transmission. Bull. Math. Biol. 73:639-657.

Chatterjee, S., Almeida, R. P. P., and Lindow, S. 2008. Living in two worlds: The plant and insect lifestyles of Xylella fastidiosa. Annu. Rev. Phytopathol. 46:243-271.

Cornara, D., Cavalieri, V., Dongiovanni, C., Altamura, G., Palmisano, F., Bosco, D., Porcelli, F., Almeida, R. P. P., and Saponari, M. 2017a. Transmission of Xylella fastidiosa by naturally infected Philaenus spumarius (Hemiptera, Aphrophoridae) to different host plants. J. Appl. Entomol. 141: 80-87.

Cornara, D., Saponari, M., Zeilinger, A. R., de Stradis, A., Boscia, D., Loconsole, G., Bosco, D., Martelli, G. P., Almeida, R. P. P., and Porcelli, F. 2017b. Spittlebugs as vectors of Xylella fastidiosa in olive orchards in Italy. J. Pest Sci. 90:521-530.

Cornara, D., Sicard, A., Zeilinger, A. R., Porcelli, F., Purcell, A. H., and Almeida, R. P. P. 2016. Transmission of Xylella fastidiosa to grapevine by the meadow spittlebug. Phytopathology 106:1285-1290.

Costello, M. J., Steinmaus, S. J., and Boisseranc, C. J. 2017. Environmental variables influencing the incidence of Pierce's disease. Aust. J. Grape Wine Res. 23:287-295.

Coviella, C. E., Garcia, J. F., Jeske, D. R., Redak, R. A., and Luck, R. F. 2006. Feasibility of tracking within-field movements of Homalodisca coagulate (Hemiptera: Cicadellidae) and estimating its densities using fluorescent dusts in mark-release-capture experiments. J. Econ. Entomol. 99: 1051-1057.

Cunniffe, N. J., Laranjeira, F. F., Neri, F. M., de Simone, R. E., and Gilligan, C. A. 2014. Cost-effective control of plant disease when epidemiological knowledge is incomplete: Modelling Bahia bark scaling of citrus. PLOS Comput. Biol. 10:e1003753.

Dáder, B., Then, C., Berthelot, E., Ducousso, M., Ng, J. C. K., and Drucker, M. 2017. Insect transmission of plant viruses: Multilayered interactions optimize viral propagation. Insect Sci. 24:929-946.

Daugherty, M. P., and Almeida, R. P. P. 2009. Estimating Xylella fastidiosa transmission parameters: Decoupling sharpshooter number and feeding period. Entomol. Exp. Appl. 132:84-92.

Daugherty, M. P., O’Neill, S., Byrne, F., and Zeilinger, A. 2015. Is vector control sufficient to limit pathogen spread in vineyards? Environ. Entomol. 44:789-797.

Daugherty, M. P., Rashed, A., Almeida, R. P. P., and Perring, T. M. 2011. Vector preference for hosts differing in infection status: Sharpshooter movement and Xylella fastidiosa transmission. Ecol. Entomol. 36:654-662. 
Dellapé, G., Paradell, S., Semorile, L., and Delfederico, L. 2016. Potential vectors of Xylella fastidiosa: A study of leafhoppers and treehoppers in citrus agroecosystems affected by Citrus Variegated Chlorosis. Entomol. Exp. Appl. 161:92-103.

De Miranda, M. P., Villada, E. S., Lopes, S. A., Fereres, A., and Lopes, J. R. S. 2013. Influence of citrus plants infected with Xylella fastidiosa on stylet penetration activities of Bucephalogonia xanthophis (Hemiptera: Cicadellidae). Ann. Entomol. Soc. Am. 106:610-618.

EFSA. 2018a. Updated pest categorisation of Xylella fastidiosa. Online publication. European Food Safety Authority. https://www.efsa.europa.eu/en/ efsajournal/pub/5357

EFSA. 2018b. Update of the Xylella spp. host plant database. Online publication. European Food Safety Authority. https://www.efsa.europa.eu/en/ efsajournal/pub/5408

Eigenbrode, S. D., Bosque-Perez, N. A., and Davis, T. S. 2018. Insect-borne plant pathogens and their vectors: Ecology, evolution, and complex interactions. Annu. Rev. Entomol. 63:169-191.

Feil, H., Feil, W. S., and Purcell, A. H. 2003. Effects of date of inoculation on the within-plant movement of Xylella fastidiosa and persistence of Pierce's disease within field grapevines. Phytopathology 93:244-251.

Freitag, J. H. 1951. Host range of Pierce's disease virus of grapes as determined by insect transmission. Phytopathology 41:920-934.

Godefroid, M., Cruaud, A., Streito, J.-C., Rasplus, J.-Y., and Rossi, J.-P. 2018. Climate change and the potential distribution of Xylella fastidiosa in Europe. Online publication. bioRxiv 289876. https://www.biorxiv.org/content/early/2018/03/28/289876

Groves, R. L., Chen, J., and Civerolo, E. L. 2005. Spatial analysis of almond leaf scorch disease in the San Joaquin valley of California: Factors affecting pathogen distribution and spread. Plant Dis. 89:581-589.

Gruber, B. R., and Daugherty, M. P. 2013. Understanding the effects of multiple sources of seasonality on the risk of pathogen spread to vineyards: Vector pressure, natural infectivity, and host recovery. Plant Pathol. 62: 194-204.

Gutiérrez, S., Michalakis, Y., van Munster, M., and Blanc, S. 2013. Plantfeeding by insect vectors can affect life cycle, population genetics and evolution of plant viruses. Funct. Ecol. 27:610-622.

Hill, B. L., and Purcell, A. H. 1995. Acquisition and retention of Xylella fastidiosa by an efficient vector, Graphocephala atropunctata. Phytopathology 85:209-212.

Hill, B. L., and Purcell, A. H. 1997. Populations of Xylella fastidiosa in plants required for transmission by an efficient vector. Phytopathology 87: 1197-1201.

Holt, J., Jeger, M. J., Thresh, J. M., and Otim-Nape, G. W. 1997. An epidemiological model incorporating vector population dynamics applied to African cassava mosaic virus disease. J. Appl. Ecol. 34:793-806.

Hopkins, D., and Purcell, A. H. 2002. Xylella fastidiosa: Cause of Pierce's disease of grapevine and other emergent diseases. Plant Dis. 86:1056-1066.

Hyatt-Twynam, S. R., Parnell, S., Stutt, R. O. J. H., Gottwald, T. R., Gilligan, C. A.., and Cunniffe, N. J. 2017. Risk-based management of invading plant disease. New Phytol. 214:1317-1329.

Jeger, M. J., Madden, L. V., and van den Bosch, F. 2018. Plant virus epidemiology: Applications and prospects for mathematical modelling and analysis to improve understanding and disease control. Plant Dis. 102: $837-854$

Jeger, M. J., Pautasso, M., Holdenrieder, O., and Shaw, M. W. 2007. Modelling disease spread and control in networks: Implications for plant sciences. New Phytol. 174:279-297.

Jeger, M. J., van den Bosch, F., and Madden, L. V. 2004. Epidemiology of insect-transmitted plant viruses: Modelling disease dynamics and control interventions. Physiol. Entomol. 29:291-304

Jeger, M. J., van den Bosch, F., Madden, L. V., and Holt, J. 1998. A model for analysing plant-virus transmission characteristics and epidemic development. IMA J. Math. Appl. Med. Biol. 15:1-18.

Jones, K. E., Patel, N. G., Levy, M. A., Storeygard, A., Balk, D., Gittleman, J. L., and Daszak, P. 2008. Global trends in emerging infectious diseases. Nature 451:990-993.

Katsar, C. S., Hunter, W. B., and Sinisterra, X. H. 2007. Phytoreovirus-like sequences isolated from salivary glands of the glassy-winged sharpshooter Homalodisca vitripennis (Hemiptera: Cicadellidae). Fla. Entomol. 90: 196-203.

Killiny, N., and Almeida, R. P. P. 2009. Host structural carbohydrate induces vector transmission of a bacterial plant pathogen. Proc. Natl. Acad. Sci. USA 106:22416-22420.

Killiny, N., and Almeida, R. P. P. 2013. Factors affecting the initial adhesion and retention of the plant pathogen Xylella fastidiosa in the foregut of an insect vector. Appl. Environ. Microbiol. 80:420-426.

Krugner, R., and Backus, E. A. 2014. Plant water stress effects on stylet probing behaviors of Homalodisca vitripennis (Hemiptera: Cicadellidae) associated with acquisition and inoculation of the bacterium Xylella fastidiosa. J. Econ. Entomol. 107:66-74.

Krugner, R., Hagler, J. R., Groves, R. L., Sisterson, M. S., Morse, J. G., and Johnson, M. W. 2012. Plant water stress effects on the net dispersal rate of the insect vector Homalodisca vitripennis (Hemiptera: Cicadellidae) and movement of its egg parasitoid, Gonatocerus ashmeadi (Hymenoptera: Mymaridae). Environ. Entomol. 41:1279-1289.

Krugner, R., Lopes, M. T. V. de C., Santos, J. S., Beretta, M. J. B., and Lopes, J. R. S. 2000. Transmission efficiency of Xylella fastidiosa to citrus by sharpshooters and identification of two new vector species. Proc. Conf. Int. Org. Citrus Virol. 14th, Campinas, Brazil.

Kyrkou, I., Pusa, T., Ellegaard-Jensen, L., Sagot, M.-F., and Hansen, L. H. 2018. Pierce's disease of grapevines: A review of control strategies and an outline of an epidemiological model. Front. Microbiol. 9:2141.

Labroussaa, F., Zeilinger, A. R., and Almeida, R. P. P. 2016. Blocking the transmission of a noncirculative vector-borne plant pathogenic bacterium. Mol. Plant-Microbe Interact. 29:535-544

Lieth, J. H., Meyer, M. M., Yeo, K. H., and Kirkpatrick, B. C. 2011. Modeling cold curing of Pierce's disease in Vitis vinifera 'Pinot Noir' and 'Cabernet Sauvignon' grapevines in California. Phytopathology 101:1492-1500.

Lopes, J. R. S., Daugherty, M. P., and Almeida, R. P. P. 2009. Context-dependent transmission of a generalist plant pathogen: Host species and pathogen strain mediate insect vector competence. Entomol. Exp. Appl. 131:216-224.

Lopes, J. R. S., Daugherty, M. P., and Almeida, R. P. P. 2010. Strain origin drives virulence and persistence of Xylella fastidiosa in alfalfa. Plant Pathol. 59:963-971.

Lopes, J. R. S., Landa, B. B., and Fereres, A. 2014. A survey of potential insect vectors of the plant pathogenic bacterium Xylella fastidiosa in three regions of Spain. Span. J. Agric. Res. 12:795-800.

Lopes, J. R. S., Teixeira, D. C., Fernandez, N. G., Ayres, A. J., Torres, S. C. Z., Barbosa, J. C., and Li, W. B. 2005. An experimental inoculation system to study citrus-Xylella fastidiosa interactions. Plant Dis. 89:250-254.

Madden, L. V., Jeger, M. J., and van den Bosch, F. 2000. A theoretical assessment of the effects of vector-virus transmission mechanism on plant virus disease epidemics. Phytopathology 90:576-594.

Maixner, M., Albert, A., and Johannesen, J. 2014. Survival relative to new and ancestral host plants, phytoplasma infection, and genetic constitution in host races of a polyphagous insect disease vector. Ecol. Evol. 4:3082-3092.

Mann, R. S., Ali, J. G., Hermann, S. L., Tiwari, S., Pelz-Stelinski, K. S., Alborn, H. T., and Stelinski, L. L. 2012. Induced release of a plant-defense volatile 'deceptively' attracts insect vectors to plants infected with a bacterial pathogen. PLoS Pathog. 8:e1002610.

Marucci, R. C., Lopes, J. R. S., and Corrente, J. E. 2003. Análise comparativa da eficiência de transmissão de Xylella fastidiosa por cigarrinhas (Hemiptera, Cicadellidae) em plantas de citros e café. Fitopatol. Bras. 28:392.

Marucci, R. C., Lopes, J. R. S., Vendramim, J. D., and Corrente, J. E. 2005. Influence of Xylella fastidiosa infection of citrus on host selection by leafhopper vectors. Entomol. Exp. Appl. 117:95-103.

Mauck, K. E., De Moraes, C. M., and Mescher, M. C. 2016. Effects of pathogens on sensory-mediated interactions between plants and insect vectors. Curr. Opin. Plant Biol. 32:53-61.

Novotny, V., and Wilson, M. R. 1997. Why are there no small species among xylem-sucking insects? Evol. Ecol. 11:419-437.

Nunney, L., Vickerman, D. B., Bromley, R. E., Russell, S. A., and Hartman, J. R. 2013. Recent evolutionary radiation and host plant specialization in the Xylella fastidiosa subspecies native to the United States. Appl. Environ. Microbiol. 79:2189-2200.

Orlovskis, Z., Canale, M. C., Thole, V., Pecher, P., Lopes, J. R. S., and Hogenhout, S. A. 2015. Insect-borne plant pathogenic bacteria: Getting a ride goes beyond physical contact. Curr. Opin. Insect Sci. 9:16-23.

Overall, L. M., and Rebek, E. J. 2015. Seasonal abundance and natural inoculativity of insect vectors of Xylella fastidiosa in Oklahoma tree nurseries and vineyards. J. Econ. Entomol. 108:2536-2545.

Overall, L. M., and Rebek, E. J. 2017. Insect vectors and current management strategies for diseases caused by Xylella fastidiosa in the southern United States. J. Int. Pest Manage. 8:1-12.

Park, Y. L., Perring, T. M., Krell, R. K., Hzshim-Buckey, J. M., and Hill, B. L. 2011. Spatial distribution of Pierce's Disease Related to incidence, vineyard characteristics and surrounding land uses. Am. J. Enol. Vitic. 62:229-238.

Park, Y. L., Perring, T. M., Yacoub, R., Bartels, D. W., and Elms, D. 2006. Spatial and temporal dynamics of overwintering Homalodisca coagulate (Hemiptera: Cicadellidae). J. Econ. Entomol. 99:1936-1942.

Parnell, S., van den Bosch, F., Gottwald, T., and Gilligan, C. A. 2017. Surveillance to inform control of emerging plant diseases: An epidemiological perspective. Annu. Rev. Phytopathol. 55:591-610.

Patt, J. M., and Sétamou, M. 2007. Olfactory and visual stimuli affecting host plant detection in Homalodisca coagulata (Hemiptera: Cicadellidae). Environ. Entomol. 36:142-150. 
Perilla-Henao, L. M., and Casteel, C. L. 2016. Vector-borne bacterial plant pathogens: Interactions with Hemipteran insects and plants. Front. Plant Sci. 7:1163.

Perring, T., Farrar, C., and Blua, M. 2001. Proximity to citrus influences Pierce's disease in Temecula Valley vineyards. Calif. Agric. 55:13-18.

Purcell, A. H. 2013. Paradigms: Examples from the bacterium Xylella fastidiosa. Annu. Rev. Phytopathol. 51:339-356.

Purcell, A. H., and Finlay, A. H. 1979. Evidence for noncirculative transmission of Pierce's disease bacterium by sharpshooter leafhoppers. Phytopathology 69:393-395.

Purcell, A. H., Saunders, S. R., Hendson, M., Grebus, M. E., and Henry, M. J. 1999. Causal role of Xylella fastidiosa in oleander leaf scorch dis- ease. Phytopathology 89:53-58.

Rajabaskar, D., Bosque-Pérez, N. A., and Eigenbrode, S. D. 2014. Preference by a virus vector for infected plants is reversed after virus acquisition. Virus Res. 186:32-37.

Rashed, A., Daugherty, M. P., and Almeida, R. P. P. 2011. Grapevine genotype susceptibility to Xylella fastidiosa does not predict vector transmission success. Environ. Entomol. 40:1192-1199.

Rathé, A. A., Pilkington, L. J., Gurr, G. M., Hoddle, M. S., Daugherty, M. P., Constable, F. E., Luck, J. E., Powell, K. S., Fletcher, M. J., and Edwards, O. R. 2012. Incursion preparedness: Anticipating the arrival of an economically important plant pathogen Xylella fastidiosa Wells (Proteobacteria: Xanthomonadaceae) and the insect vector Homalodisca vitripennis (Germar) (Hemiptera: Cicadellidae) in Australia. Aust. J. Entomol. 51: 209-220.

Redak, R. A., Purcell, A. H., Lopes, J. R. S., Blua, M. J., Mizell, R. F., and Andersen, P. C. 2004. The biology of xylem fluid-feeding insect vectors of Xylella fastidiosa and their relation to disease epidemiology. Annu. Rev. Entomol. 49:243-270.

Roberts, M. G., and Heesterbeek, J. A. P. 2007. Model-consistent estimation of the basic reproductive number from the incidence of an emerging infection. J. Math. Biol. 55:803-816.

Roosien, B. K., Gomulkiewicz, R., Ingwell, L. L., Bosqe-Pérez, N. A., Rajabaskar, D., and Eigenbrode, S. D. 2013. Conditional vector preference aids the spread of plant pathogens: Results from a model. Environ. Entomol. 42:1299-1308.

Roossinck, M. J. 2002. Evolutionary history of cucumber mosaic virus deduced by phylogenetic analyses. J. Virol. 76:3382-3387.

Sanderlin, R. S. 2017. Host specificity of pecan strains of Xylella fastidiosa subsp. multiplex. Plant Dis. 101:744-750.

Saponari, M., Boscia, D., Altamura, G., D’Attoma, G., Cavalieri, V., Loconsole, G., Zicca, S., Dongiovanni, C., Palmisano, F., Susca, L., Morelli, M., Potere, O., Saponari, A., Fumarola, G., Di Carolo, M., Tavano, D., Savino, V., and Martelli, P. 2016. Pilot project on Xylella fastidiosa to reduce risk assessment uncertainties. EFSA Supporting Publ. 13:1013E.

Saponari, M., Boscia, D., Altamura, G., Loconsole, G., Zicca, S., D’Attoma, G., Morelli, M., Palmisano, F., Saponari, A., Tavano, D., Savino, V. N., Dongiovanni, C., and Martelli, G. P. 2017. Isolation and pathogenicity of Xylella fastidiosa associated to the olive quick decline syndrome in southern Italy. Sci. Rep. 7: Article 17723.

Shaw, A. K., Peace, A., Power, A. G., and Bosque-Perez, N. 2017. Vector population growth and condition-dependent movement drive the spread of plant pathogens. Ecology 98:2145-2157.

Shi, R., Zhao, H., and Tang, S. 2014. Global dynamic analysis of a vectorborne plant disease model. Adv. Differ. Eqns. 2014:59.

Sicard, A., Zeilinger, A. R., Vanhove, M., Schartel, T. E., Beal, D. J., Daugherty, M. P., and Almeida. R. P. P. 2018. Xylella fastidiosa: Insights into an emerging plant pathogen. Annu. Rev. Phytopathol. 56:181-202.
Simon, J.-C., Biere, A., and Sugio, A. 2017. The promises and challenges of research on plant-insect-microbe interactions. Insect Sci. 24:904-909.

Sisterson, M. S. 2009. Transmission of insect-vectored pathogens: Effects of vector fitness as a function of infectivity status. Environ. Entomol. 38:345-355.

Sisterson, M. S., Krugner, R., Wallis, C. M., and Stenger, D. C. 2018. Effects of energy reserves and diet on glassy-winged sharpshooter egg maturation. J. Econ. Entomol. 111:159-169.

Sisterson, M. S., Ledbetter, C. A., Chen, J., Higbee, B. S., Groves, R. L., and Daane, K. M. 2012. Management of almond leaf scorch disease: Long-term data on yield, tree vitality, and disease progress. Plant Dis. 96:1037-1044.

Sisterson, M. S., and Stenger, D. C. 2016. Disentangling effects of vector birth rate, mortality rate, and abundance on spread of plant pathogens. J. Econ. Entomol. 109:487-501.

Sisterson, M. S., and Stenger, D. C. 2018. Modelling effects of vector acquisition threshold on disease progression in a perennial crop following deployment of a partially resistant variety. Plant Pathol. 67:1.

Sisterson, M. S., Wallis, C. M., and Stenger, D. C. 2017. Effects of xylem-sap composition on glassy-winged sharpshooter (Hemiptera: Circadellidae) egg maturation on high- and low-quality host plants. Environ. Entomol. 46: 299-310.

Soubeyrand, S., de Jerphanion, P., Martin, O., Saussac, M., Manceau, C., Hendrix, P., and Lannou, C. 2018. Inferring pathogen dynamics from temporal count data: The emergence of Xylella fastidiosa in France is probably not recent. New Phytol. 219:824-836.

Stafford, C. A., and Walker, G. P. 2009. Characterization and correlation of DC electrical penetration graph waveforms with feeding behavior of beet leafhopper, Circulifer tenellus. Entomol. Exp. Appl. 130:113-129.

Stafford, C. A., Walker, G. P., and Ullman, D. E. 2012. Hitching a ride: Vector feeding and virus transmission. Commun. Integr. Biol. 5:43-49.

Stenger, D. C., Sisterson, M. S., and French, R. 2010. Population genetics of Homalodisca vitripennis reovirus validates timing and limited introduction to California of its invasive insect host, the glassy-winged sharpshooter. Virology 407:53-59.

Strona, G., Carstens, C. J., and Beck, P. S. A. 2017. Network analysis reveals why Xylella fastidiosa will persist in Europe. Sci. Rep. 7: Article 71.

Tamborindeguy, C., Huot, O. B., Ibanez, F., and Levy, J. 2017. The influence of bacteria on multitrophic interactions among plants, psyllids, and pathogen. Insect Sci. 24:961-974.

van den Bosch, F., and Jeger, M. J. 2017. The basic reproduction number of vector-borne plant virus epidemics. Virus Res. 241:196-202.

Vicent, A., and Blasco, J. 2017. When prevention fails. Towards more efficient strategies for plant disease eradication. New Phytol. 214:905-908.

Wan, J., Cabanillas, D. C., Zheng, H., and Laliberté, J.-F. 2015. Turnip mosaic virus moves systemically through both phloem and xylem as membraneassociated complexes. Plant Physiol. 167:1374-1388.

Wesley, C. L., and Allen, L. J. S. 2009. The basic reproduction number in epidemic models with periodic demographics. J. Biol. Dyn. 3:116-129.

White, S. M., Bullock, J. M., Hooftman, D. A. P., and Chapman, D. S. 2017. Modelling the spread and control of Xylella fastidiosa in the early stages of invasion in Apulia, Italy. Biol. Invasions 19:1825-1837.

Wistrom, C., Sisterson, M. S., Pryor, M. P., Hashim-Buckey, J. M., and Daane, K. M. 2010. Distribution of glassy-winged sharpshooter and threecornered alfalfa hopper on plant hosts in the San Joaquin valley. Calif. J. Econ. Entomol. 103:1051-1059.

Zarco-Tejada, P. J., Camino, C., Beck, P. S. A., Calderon, R., and Hornero, A. 2018. Previsual symptoms of Xylella fastidiosa infection revealed in spectral plant-trait alterations. Nat. Plants 4:432-439.

Zeilinger, A. R., and Daugherty, M. P. 2014. Vector preference and host defense against infection interact to determine disease dynamics. Oikos 123:613-622. 